https://doi.org/10.46813/2022-137-021

\title{
STRUCTURAL-PHASE TRANSFORMATIONS IN MAGNETRON DEPOSITED FILMS OF Ti-Zr-Ni SYSTEMS DURING ANNEALING IN VACUUM
}

\author{
S.V. Malykhin, V.V. Kondratenko, I.A. Kopylets, Yu.S. Bogdanov, S.V. Surovitsky, \\ S.S. Borisova, I.G. Shipkova \\ National Technical University "Kharkiv Polytechnical Institute”, \\ Kharkiv, Ukraine \\ E-mail: serhii.malykhin@kpi.kharkov.ua
}

\begin{abstract}
Structural and phase changes in thin films obtained by magnetron sputtering of a target with the composition Ti41Zr38.3Ni20.7 (at.\%) were studied under isothermal vacuum annealing in the temperature range from 400 to $800^{\circ} \mathrm{C}$. The boundaries of the thermal stability of the phases have been determined. Coatings consisting of a single icosahedral quasicrystalline phase, as well as films consisting of the $2 / 1$ crystal-approximant phase were obtained. The features of the phase transformation of a quasicrystal into an approximant crystal were investigated, and the activation energy of this transformation was determined at a level of $94 \mathrm{~kJ} / \mathrm{mol}$. The dependence of the degree of phase transformation on the temperature and duration of annealing has been established.
\end{abstract}

PACS: $52.40 . \mathrm{HF}$

\section{INTRODUCTION}

Scientific and technological progress is determined to a large extent by success in the development and creation of materials with unique physical properties. Quasicrystals (QCs), which were discovered by D. Shekhtman in 1986 [1], became a fundamentally new type of solid body. The cardinal differences in their structure in comparison with crystals naturally make it possible to obtain a wide range of unique properties, first of all, high hardness and wear resistance, low coefficient of friction and low electrical and thermal conductivity [2].

A natural step in the practical development of quasicrystals was the mastery of the technology of making films and functional coatings of quasicrystals and compositions based on them. The wide practical use of the films is based on the specificity of their properties, which are significantly different from materials in the bulk state [3]. A feature of systems in which QC phases are formed is the existence of phases of crystalline approximants (AP) phases. The structures of both QCs and AR are formed on the basis of one or more clusters with non-crystallographic symmetry, which fill the space non-periodically; but if in quasicrystals the clusters are located non-periodically, then in approximants of rank $2 / 1$ and higher, the cluster, as a structural unit, is repeated periodically [4]. It is of interest to study the features of the formation of the AP phases, "relatives" of QCs, and the subsequent study of their properties. Earlier [5], we first noted the existence of the 2/1AP phase in the Ti-Zr-Ni system.

The aim of this work was to study the structuralphase transformations of the Ti-Zr-Ni films upon annealing in vacuum, to determine the limits of the temperature stability of the phases, and also to elucidate the features of the formation of the 2/1 AP phase.

\section{SAMPLES AND INVESTIGATION TECHNIQUE}

The films were prepared by dc-magnetron sputtering of the target. The details of laboratory technology for the preparation of the coatings are described in the previous work [6].

The alloys for the target were made at the NSC KIPT from nickel, titanium and zirconium refined by double electron-beam melting in an ultrahigh-vacuum installation with an ultimate vacuum of at least $10^{-6} \mathrm{~Pa}$. To obtain the composition Ti41Zr38.3Ni20.7 (at.\%), the components were taken in nominal amounts. The composition was chosen so that its electron concentration $e / a=1.19$ was close to the cross section of constant concentration $e / a=1.20$, which is characteristic of the quasicrystal.

The elemental composition of the target and prepared films was controlled by X-ray fluorescence analysis [7]. Austenitic polished steel was used as substrates. The substrate temperature during deposition was $323 \mathrm{~K}$.

Sputtering was carried out in a purified argon atmosphere at a pressure of $2 \cdot 10^{-1} \mathrm{~Pa}$. The thickness of the films was 14.6 and $6.7 \mu \mathrm{m}$. After deposition, the films were isothermally annealed in vacuum at a pressure of $6 \cdot 10^{-4} \mathrm{~Pa}$ for $1 \mathrm{~h}$ at temperatures ranging from 400 to $800{ }^{\circ} \mathrm{C}$ with a step of 50 degrees. Some films were annealed for a long time for up to $60 \mathrm{~h}$.

The structure and phase composition were investigated by XRD. The measurements were carried out on a DRON-type apparatus in filtered $\mathrm{Cu}-\mathrm{K \alpha}$ radiation. The diffraction spectra were processed using the New Profile 3.5 software package. According to the method by J.W. Cahn [8], the QC phase was identified, its reflections were indexed with two indices $(\mathrm{N}, \mathrm{M})$, and its quasicrystallinity parameter $a_{\mathrm{q}}$ was determined. To construct line X-ray diffraction patterns of possible crystalline phases: crystal-approximant $1 / 1$ (W-phase), Laves phase $(\mathrm{Ti}, \mathrm{Zr})_{2} \mathrm{Ni}$ (L, structural type $\mathrm{C} 14$ ), and 
$\alpha-\operatorname{Ti}(\mathrm{Zr})$ solid solution, we used the Powder Cell software package. Reflections from the phase of the 2/1 approximant with a primitive cubic cell were indexed by the classical method for crystals [9].

\section{RESULTS AND DISCUSSION}

As shown in $[5,6]$, in the initial state, immediately after deposition, the films are X-ray amorphous, with a disordered state that is topologically close to icosahedral in the nearest atomic environment. The system of diffraction maxima is formed when the annealing temperature reaches $400{ }^{\circ} \mathrm{C}$ (Fig. 1). With an increase in temperature to $450 \ldots 500{ }^{\circ} \mathrm{C}$, the diffraction maxima become more pronounced, their number becomes more and more. All of them are indexed without gaps as belonging to the icosahedral QC phase with one value of the quasicrystalline parameter.

An increase in temperature to $550 \ldots 600{ }^{\circ} \mathrm{C}$ leads to the appearance of additional reflections in the spectrum, which are not inherent either in the QC phase, or other equilibrium crystalline phases. The diffraction patterns show a characteristic maximum located at a diffraction angle of $2 \vartheta \approx 32.2 \ldots 32.4$ degrees. The intensity of this maximum increases with an increase in the annealing temperature. In addition, there is a shift of the strongest reflections which were previously identified as reflections $(18,29)$ and $(20,32)$ from the icosahedral phase. Moreover, the first is shifted towards smaller, and the second towards larger angles. As a result, the values of the quasicrystallinity parameter calculated from their positions differ significantly more than the measurement error. Since this is unacceptable for the same phase, this fact means that there is not a QC phase, but a new phase that has not been detected previously [10-12]. We identified this phase as a crystal approximant 2/1 [5]. Initially, such a phase with the $\mathrm{Pa} \overline{3}$ structure type was observed in the $\mathrm{Zn}-\mathrm{Mg}-\mathrm{Al}$ system [13]. Processing of diffraction patterns using the New Profile 3.5 program including smoothing, background separation, and separation of the $K \alpha$ doublet, revealed that reflections from samples annealed in the range from 450 to $700 \ldots 750{ }^{\circ} \mathrm{C}$ are characterized by asymmetry of the strongest maxima $(18,29)$ and $(20$, 32). Apparently, they consist of two symmetrical profiles, slightly offset from each other. This fact can be interpreted as the coexistence of two phases, namely, QC and AP; and the parameters of their structures are naturally related [4]. It was found that the temperature range of coexistence of these phases with an annealing duration of $1 \mathrm{~h}$ extends to $700{ }^{\circ} \mathrm{C}$.

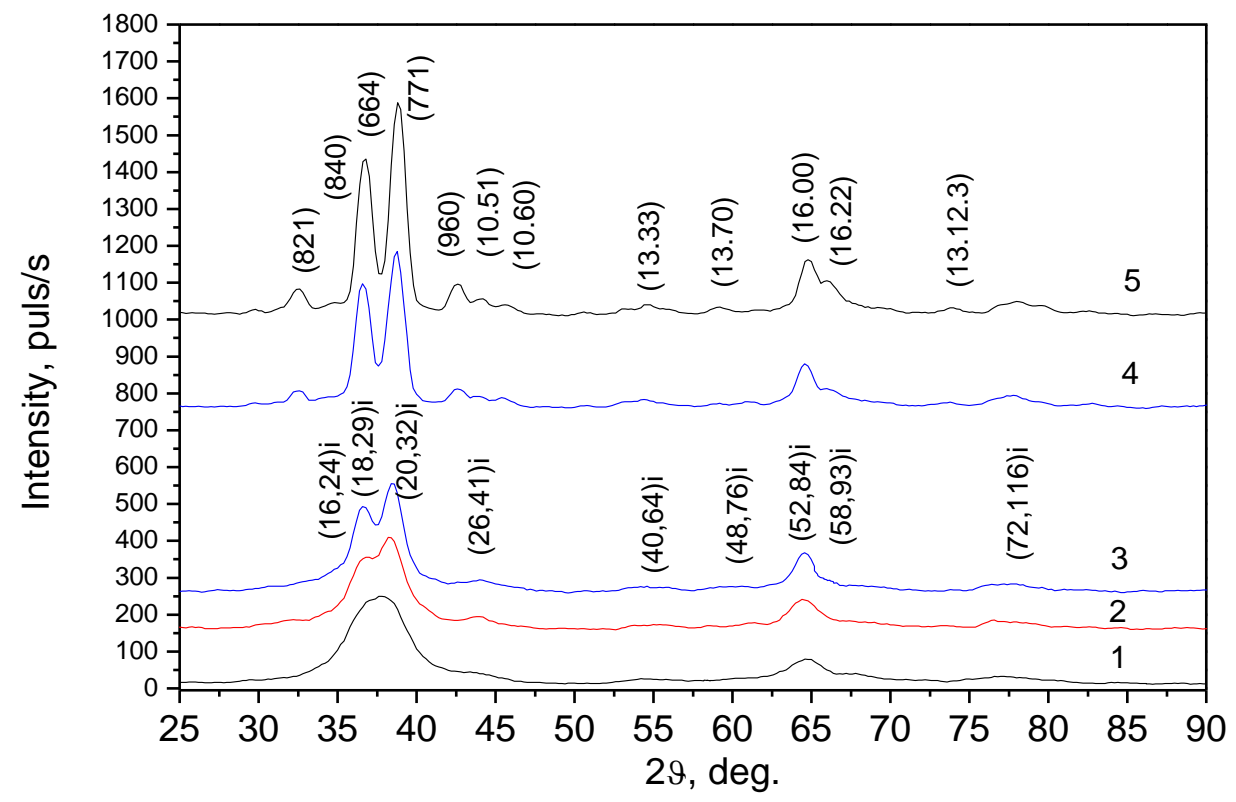

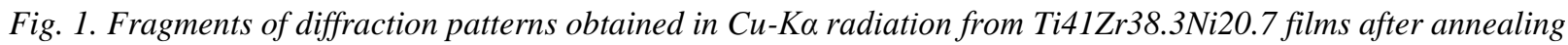
for an hour at temperatures of 400 (1); 450 (2); 500 (3); 550(4), and $600{ }^{\circ} \mathrm{C}$ (5)

Using long-term annealing, we found that annealing for $28 \mathrm{~h}$ at $470{ }^{\circ} \mathrm{C}$ leads to the formation of a singlephase quasicrystalline state. An increase in the annealing time to $50 \mathrm{~h}$ promotes the appearance of reflection (653) from the approximant phase. Annealing at $570{ }^{\circ} \mathrm{C}$ for $60 \mathrm{~h}$ forms a single-phase state with only the 2/1 approximant present. The corresponding diffraction patterns are shown in Fig. 2.

The figure shows how the given diffraction patterns from these related phases are similar and at the same time how different they are. Based on the obtained data, the QC phase is stable in the films after prolonged annealing at temperatures no higher than $500{ }^{\circ} \mathrm{C}$; it coexists with the AP 2/1 phase after short-term annealing up to $750{ }^{\circ} \mathrm{C}$. Moreover, at high annealing temperatures, the formation of the Laves phase ( $\mathrm{Ti}, \mathrm{Zr})_{2} \mathrm{Ni}$ and a solid solution $\alpha-\mathrm{Ti}(\mathrm{Zr})$ characteristic of the phase diagram [12] is observed. Thus, the optimal conditions for the formation of single-phase 2/1AP films are long-term annealing (tens of hours) at a temperature of about $570{ }^{\circ} \mathrm{C}$, and for the QC phase - at about $470{ }^{\circ} \mathrm{C}$ for duration of no more than $30 \mathrm{~h}$. 


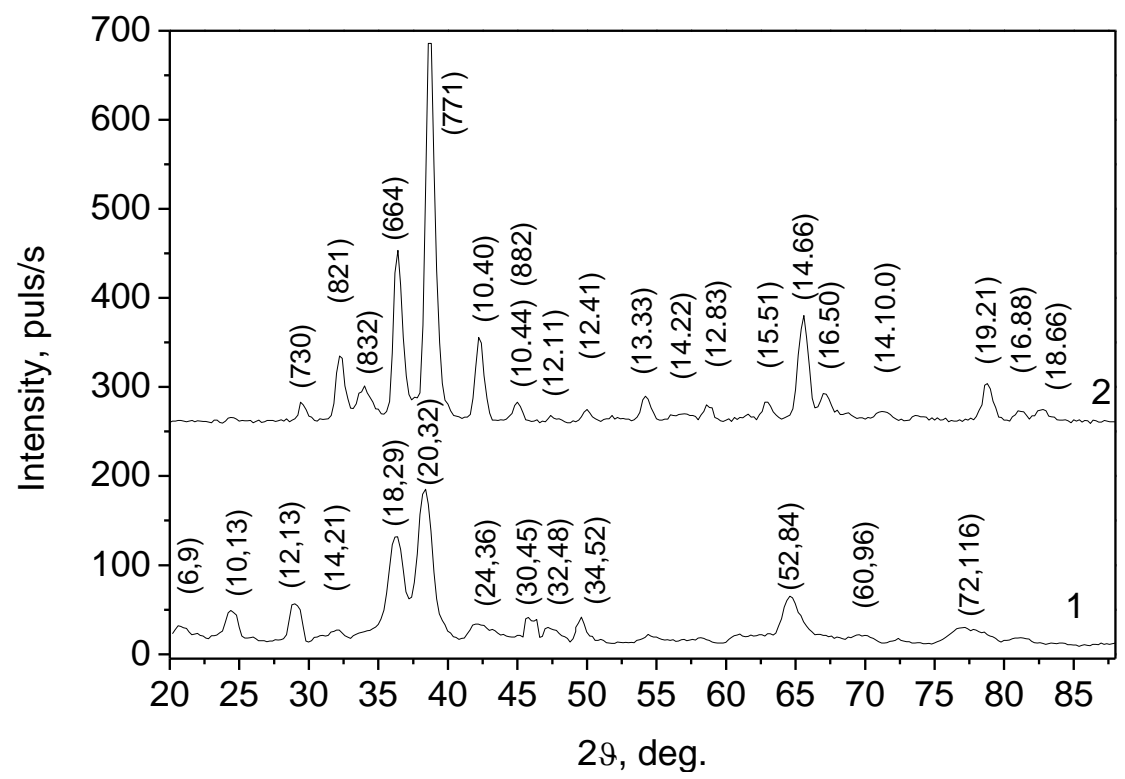

Fig. 2. Fragments of diffraction patterns obtained in $\mathrm{Cu}-K_{\alpha}$ radiation from Ti41Zr38.3Ni20.7 films annealed at temperatures of $470(1)$ and $570{ }^{\circ} \mathrm{C}(2)$ for 28 and $20 \mathrm{~h}$, respectively

As noted above, the parameters of the QC and 2/1AP structures are naturally related. Fig. 3 shows the change in the quasicrystallinity parameter $a_{\mathrm{q}}$ of the QC phase and the lattice period $a_{2 / 1}$ of the $2 / 1 \mathrm{AP}$ phase with an increase in the annealing temperature.

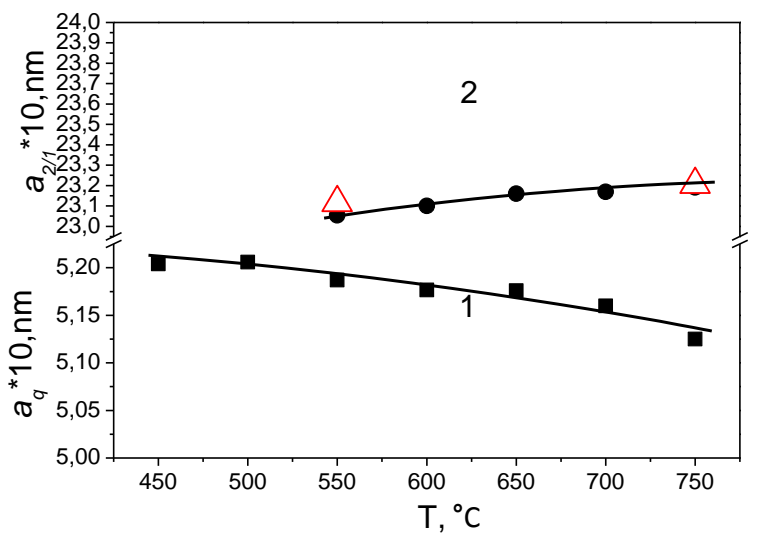

Fig. 3. Changes in the quasicrystallinity parameter (1) of the QC phase and the lattice period (2) of the AP phase with an increase in the annealing temperature

The behavior of the temperature dependences of the parameters (see Fig. 3) and the nature of the changes in the diffraction patterns of the structures in Fig. 1 assumes the occurrence of the phase transformation $\mathrm{QC} \rightarrow 2 / 1 \mathrm{AP}$, accompanied by the redistribution of the components. Proceeding from the fact that the intensity of reflections from the phase is proportional to the volume (mass) fraction of this phase in the sample, we plotted the dependence of the intensity of the standalone reflection (821) of the AP phase on the reciprocal temperature in the shape of the Arrhenius graph (Fig. 4).

The experimental points fit well with the straightline relationship. The activation energy of the phase transformation $\mathrm{QC} \rightarrow 2 / 1 \mathrm{AP}$ calculated from this dependence turned out to be $94 \mathrm{~kJ} / \mathrm{mol}$. Based on this value, it can be argued that the transformation is not classically diffusive. Atomic jumps occur at distances insignificantly different from atomic dimensions.

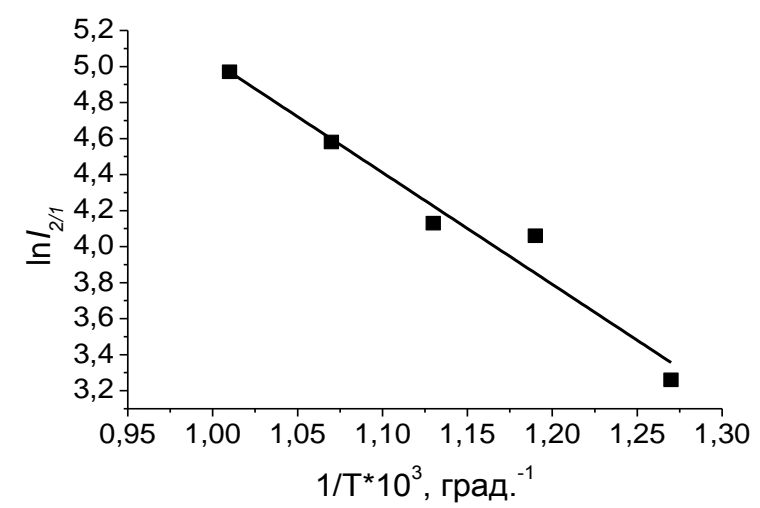

Fig. 4. Dependence of the logarithm of the reflection intensity (821) of the AP 2/1 phase on the inverse temperature of annealing for one hour

In terms of energy, this transformation turns out to be similar to the so-called normal phase transformation, because its kinetics is similar to the transformations in the solid state observed during crystallization [14]. Then, changes in the parameters of the structures $a_{\mathrm{q}}$ and $a_{2 / 1}$ in Fig. 3 should not be associated with a significant redistribution of components between the phases. This is also evidenced by the following fact. The parameters $a_{\mathrm{q}}$ and $a_{2 / 1}$ are crystallographically related by the strict expression

$$
a_{q / p}=\frac{2(p+q \cdot \tau)}{\sqrt{2+\tau}} \cdot a_{q}[16],
$$

where $q / p$ is the rank of the approximant (in our case $2 / 1$ ) and $\tau=1.618 \ldots$ is the golden number. A noticeable formation of the AP phase is observed at $550{ }^{\circ} \mathrm{C}$. The value of the lattice period $a_{2 / 1}$ calculated for this temperature from the value of the parameter $a_{\mathrm{q}}$ gives the value marked with a triangle on the graph Fig. 3. It matches the measured value. At a temperature of $750{ }^{\circ} \mathrm{C}$, the value of the period $a_{2 / 1}$ calculated from $a_{\mathrm{q}}$ for a single-phase quasicrystal also coincides with the experimental value. This means that, during the transformation, the elemental composition does not 
change significantly, but there are changes of the coordination in the arrangement of atoms and, possibly, in the characteristics of the defectiveness of the structure.

Fig. 5 shows the change in half-width of the $(18,29)$ reflection of QC and (664) reflection of AP. Since they are located at small diffraction angles, only the size of the coherent scattering regions and specific for QC phason defects can make the main contribution to the broadening. It follows from the figure that an increase in the annealing temperature promotes a change in the structural state of the QC and AP phases. It consists in an increase in the coherence length along the normal to the film surface. We assume that a decrease in the broadening of reflections can also be associated with the annealing of chaotically distributed phason defects of growth, which cause microstrains of the structure and broadening of reflections.

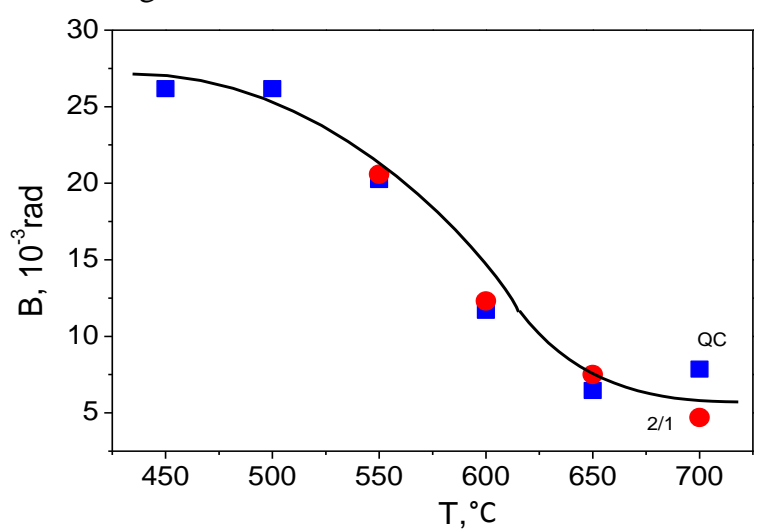

Fig. 5. Changes in the half-width of reflections from the $Q C$ phase (squares) and from the AP phase (circles) with an increase in the annealing temperature

Annealing and the formation of walls of linear phason defects should cause a shift in reflections [15, 16]. It is convenient to express the displacement as $\Delta a_{q}=a_{q 0}-a_{q T}$, where $a_{q 0}$ is the quasicrystallinity parameter for the sample annealed for $28 \mathrm{~h}$. It is calculated from reflections at large diffraction angles and weakly sensitive to the presence of phasons. This value was chosen as a reference value under the assumption that prolonged annealing of a single-phase quasicrystal removed all defects. The $a_{q T}$ value is a parameter for a sample at a certain annealing temperature. Fig. 6 shows the dependence of the parameter $\Delta a_{q}$ on temperature.

It is seen that the parameter $\Delta a_{q}$ increases with an increase in the annealing temperature. This fact, in our opinion, indicates precisely the accumulation of linear phason defects in the QC phase. According to theoretical concepts [17], phase transitions of the quasicrystal-to-crystal type can be initiated by spontaneously arising phason deformations. Apparently, this also takes place in our experiments, and suggests the mechanism of the $\mathrm{QC} \rightarrow 2 / 1 \mathrm{AP}$ phase transformation.

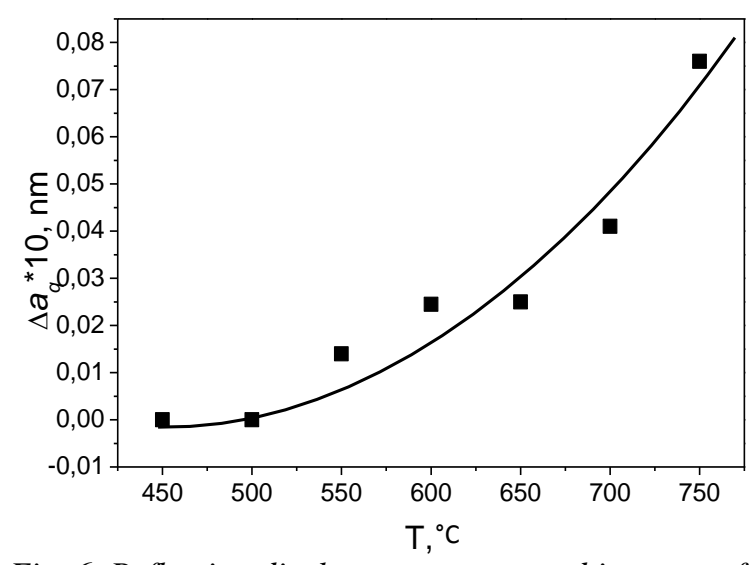

Fig. 6. Reflection displacement expressed in terms of the change in the quasicrystallinity parameter as a function of the annealing temperature

In Fig. 5, it can be noted that the change in the halfwidth of reflections from both phases is the same by the magnitude. This may mean that the transformation occurs in the volume of each individual crystallite. An increase in the annealing temperature above 750 to $850{ }^{\circ} \mathrm{C}$ with an annealing duration of $1 \mathrm{~h}$ contributes to a decrease in the content of the approximant phase and an increase in the number of crystalline phases that are thermodynamically stable at these temperatures: Laves phases $(\mathrm{Ti}, \mathrm{Zr})_{2} \mathrm{Ni}(L$, structural type $\mathrm{C} 14)$ and solid solution $\alpha$-Ti (Zr) [12-14].

\section{CONCLUSIONS}

Phase changes in magnetron-deposited coatings of the composition Ti41Zr38.3Ni20.7 (at.\%) were experimentally investigated during isothermal vacuum annealing in the temperature range from 400 to $800{ }^{\circ} \mathrm{C}$ with a step of $50{ }^{\circ} \mathrm{C}$ for $1 \mathrm{~h}$. It was determined that in the temperature range from 450 to $750{ }^{\circ} \mathrm{C}$ after $1 \mathrm{~h}$ of annealing, a phase transformation of the QC phase into the phase of a $2 / 1$ crystal-approximant $(\mathrm{QC} \rightarrow 2 / 1 \mathrm{AP}$ ) occurs with an activation energy of $94 \mathrm{~kJ} / \mathrm{mol}$ sufficient for the movement of individual atoms over small distances. The limits of the existence of the phases in thin-film coatings arehave been established and it has been shown that a single-phase QC film is formed by annealing for $28 \mathrm{~h}$ at $470{ }^{\circ} \mathrm{C}$; a single-phase film of the $2 / 1 \mathrm{AP}$ is formed by annealing at $570^{\circ} \mathrm{C}$ for $20 \mathrm{~h}$.

\section{REFERENCES}

1. D. Shechtman, I. Blech, D. Gratias, J.W. Cahn. Metallic phase with long-rage orientational order and no translational symmetry // Phys. Rev. Lett. 1984, v. 53, p. 1951-1953.

2. Z. Stadnik. Physical properties of quasicrystals. Berlin: "Springer", 1999, 365 p.

3. L.S. Palatnik, M.Ya. Fuks, V.M. Kosevich. Mechanism of Formation and Substructure of Condensed Films. M.: "Nauka", 1972, 319 p.

4. W. Steurer, S. Deloudi. Crystallography of Quasicrystals. Concepts, Methods and Structures. Berlin: "Springer", 2009, 384 p. 
5. S.V. Malykhin, V.V. Kondratenko, I.A. Kopylets, S.V. Surovitskiy, I.G. Shipkova, I.F. Mikhailov, E.N. Zubarev, Yu.S. Bogdanov. Features of the initial stage of the formation of $\mathrm{Ti}-\mathrm{Zr}-\mathrm{Ni}$ quasicrystalline thin films // J. of Nano- and Electronic Physics. 2020, v. 12, N 4, p. 04011.

6. S.V. Malykhin, V.V. Kondratenko, I.A. Kopylets, S.V. Surovitskiy, A.A. Baturin, I.F. Mikhailov, M.V. Reshetnyak, S.S. Borisova, Yu.S. Bogdanov // J. Nano- and Electronic Physics. 2019, v. 11, N3, p. 03009.

7. I.F. Mikhailov, A.A. Baturin, A.I. Mikhailov. Analyzing Materials Using Joint $X$-ray Fluorescence and Diffraction Spectra. Cambridge, UK: "Cambridge Scholars Publishing Ltd", 2020, 237 p.

8. J. Cahn, D. Shechtman, D. Grafias. Indexing of icosahedral quasiperiodic crystals // J. Mat. Res. 1986, v. 1, N 1, p. 30-54.

9. S.S. Gorelik, Yu.A. Skakov, L.N. Rastorguev. Xray and electron-optical analysis. M.: MISIS, 1994, $328 \mathrm{p}$.

10. S. Yi, D. Kim. Stability and phase transformations of icosahedral phase in a 41.5Zr41.5Ti17Ni alloy // J. Mater. Res. 2000, v. 15, N 4, p. 892-897.

11. R.G. Hennig, K.F. Kelton, A.E. Carlsson, C.L. Henly. Structure of the icosahedral Ti-Zr-Ni quasicrystal // Physical Review B: Condensed Matter and Materials Physics. 2003, v. 67, p. 134202/1134202/13.

12. K.F. Kelton, A.K. Gangopadhyay, G.W. Lee, et al. X-ray and electrostatic levitation undercooling studies in Ti-Zr-Ni quasicrystal forming alloys // Journal of Non-Crystalline Solids. 2002, v. 312-314, p. 305-308.

13. Q. Lin, J.D. Corbett. New building blocks in the 2/1 crystalline approximant of a Bergman-type icosahedral quasicrystal // PNAS. 2006, v. 103, N 37, p. 13589-13594.

14. R.U. Kahn, P.T. Haazen. Physical metallurgy, V. 2. Phase transformations in metals and alloys and alloys with special physical properties / Trans. from English. M.: "Metallurgy", 1987, 624 p.

15. M. Jono, Y. Matsuo, K. Yamamoto. X-ray diffraction study of phason strain in an $\mathrm{Al}-\mathrm{Cu}-\mathrm{Fe}$ icosahedral quasicrystal // Phil. Mag. 2001, v. 81, N 11, p. 2577-2590.

16. A. Letoublon, F. Yakov, F. Livet, et al. X-ray diffraction and phason fluctuations in quasicrystals // Europhys. Lett. 2001, v. 54, N 6, p. 753-759.

17. Sh.Kh. Hannanov. Phase deformations as a mechanism of phase transition in quasicrystals // Physics of Metals and Metal Science. 2006, v. 101, N 5 , p. $453-461$.

\title{
СТРУКТУРНО-ФАЗОВЫЕ ПРЕВРАЩЕНИЯ В МАГНЕТРОННО-ОСАЖДЕННЫХ ПЛЕНКАХ Ti-Zr-Ni-CИСТЕМЫ ПРИ ОТЖИГЕ В ВАКУУМЕ
}

\author{
С.В. Малыхин, В.В. Кондратенко, И.А. Копылец, Ю.С. Богданов, \\ С.В. Суровицкий, С.С. Борисова, И.Г. Шипкова
}

Исследованы структурно-фазовые изменения в тонких пленках, полученных магнетронным распылением мишени состава Ti41Zr38,3Ni20,7 (ат.\%), при изотермических вакуумных отжигах в интервале температур $400 \ldots 800{ }^{\circ} \mathrm{C}$. Определены границы термической стабильности фаз. Получены однофазные покрытия из икосаэдрической квазикристаллической фазы, а также из фазы кристалла-аппроксиманта 2/1. Исследован характер фазового превращения квазикристалла в кристалл-аппроксимант, и определена энергия активации этого превращения на уровне 94 кДж/моль. Установлена зависимость степени фазового превращения от температуры и продолжительности отжига.

\section{СТРУКТУРНО-ФАЗОВІ ПЕРЕТВОРЕННЯ В МАГНЕТРОННО-ОСАДЖЕНИХ ПЛІВКАХ Ti-Zr-Ni-СИСТЕМИ ПРИ ВІДПАЛІ У ВАКУУМІ}

\section{С.В. Малихін, В.В. Кондратенко, І.А. Копилець, Ю.С. Богданов, С.В. Суровицький, С.С. Борисова, І.Г. Шипкова}

Досліджено структурно-фазові зміни в тонких плівках, отриманих магнетронним розпиленням мішені складу Ti41Zr38,3Ni20,7 (ат.\%), при ізотермічних вакуумних відпалах в інтервалі температур $400 \ldots 800{ }^{\circ} \mathrm{C}$. Визначено межі термічної стабільності фаз. Отримано однофазні покриття з ікосаедричної квазікристалічної фази, а також з фази кристала-апроксиманта 2/1. Досліджено характер фазового перетворення квазікристала в кристал-апроксимант, і визначена енергія активації цього перетворення на рівні 94 кДж/моль. Встановлено залежність ступеня фазового перетворення від температури і тривалості відпалу. 